\title{
Signal Penetration towards Wooden Building Construction Materials
}

\author{
L.C. Kho ${ }^{1}$, S.S Ngu ${ }^{2}$, A.Baharun ${ }^{3}$ and K.Lias ${ }^{4}$ \\ ${ }^{1,2,4}$ Department of Electronics, Faculty of Engineering, Universiti Malaysia Sarawak, 94300 Kota Samarahan \\ 3 Department of Civil, Faculty of Engineering, University Malaysia Sarawak, 94300 Kota Samarahan \\ 1ckho@feng.unimas.my, ssngu@feng.unimas.my, bazhaili@feng.unimas.my, 1kasumawati@feng.unimas.my
}

\begin{abstract}
This paper emphasize on the effect of mobile signal penetration towards wooden building construction materials in Malaysia. The results of signal strength measurement at frequency $900 \mathrm{MHz}$ in the anechoic chamber with different types of wooden building construction materials and thickness is presented. The objectives of these experiments are to identify the types of wooden building materials in Malaysia that have significant impact into signal penetration and determine the effect of the identified wooden materials thickness towards signal penetration into building materials. This paper also report on the anechoic chamber and experiment setup that is used in the experiment.
\end{abstract}

\section{Introduction}

Wood has become an important commodity in human life. It has been used in most of human life especially as a construction material and also as a source of energy. In Malaysia woods can be mainly divided into four main categories; heavy hardwoods, medium hardwoods, light hardwood and softwood. Another type of wood base that used as a construction material is plywood. Table 1-4 shows some examples of the wood in each category and Table 5 shows the plywood characteristics [1-3].

Table 1: Heavy Hardwood

\begin{tabular}{|l|l|}
\hline \multicolumn{1}{|c|}{ Type of wood } & \multicolumn{1}{|c|}{ Wood description } \\
\hline $\begin{array}{l}\text { Balau/Selagan } \\
\text { Batu } \\
\text { Shorea spp.) }\end{array}$ & $\begin{array}{l}\text { Used in all forms of heavy } \\
\text { construction, bridges, piling, } \\
\text { beams, wharves, and others. }\end{array}$ \\
\hline $\begin{array}{l}\text { Belian } \\
\text { (Eusideroxylon } \\
\text { zwageri) }\end{array}$ & $\begin{array}{l}\text { Used in heavy construction, marine } \\
\text { piling, boat construction, shaves, } \\
\text { fence posts, heavy-duty industrial } \\
\text { flooring, and vehicle bodywork. }\end{array}$ \\
\hline $\begin{array}{l}\text { Merbau } \\
\text { Intsia } \\
\text { palembanica, I. } \\
\text { bijuga) }\end{array}$ & $\begin{array}{l}\text { The growth ring figure and deep } \\
\text { colour makes it an attractive wood } \\
\text { for decorative work including } \\
\text { interior finishing, and others. }\end{array}$ \\
\hline
\end{tabular}

Table 2: Medium Hardwood

\begin{tabular}{|l|l|}
\hline Type of wood & \multicolumn{1}{|c|}{ Wood description } \\
\hline $\begin{array}{l}\text { Kempas } \\
\text { (Koompassia } \\
\text { malaccensis) }\end{array}$ & $\begin{array}{l}\text { Used in heavy construction, railway } \\
\text { sleepers, transmission posts, beams, } \\
\text { piling, joists, bridges, fence posts, } \\
\text { wharves, parquet and strip flooring, } \\
\text { paneling, heavy-duty furniture and } \\
\text { pallets, boxes, crates and tool } \\
\text { handles. }\end{array}$ \\
\hline $\begin{array}{l}\text { Kapur } \\
\text { (Dryobalanops } \\
\text { spp.) }\end{array}$ & $\begin{array}{l}\text { Used in heavy and medium } \\
\text { construction, heavy-duty flooring, } \\
\text { joists, beams, furniture, rafters, tool } \\
\text { handles, door and window frames, } \\
\text { pallets, boxes and crates. }\end{array}$ \\
\hline $\begin{array}{l}\text { Keruing } \\
\text { (Dipterocarpus } \\
\text { spp. })\end{array}$ & $\begin{array}{l}\text { Used in heavy and general building } \\
\text { construction, bridges, framework of } \\
\text { wagons and wagon flooring, railway } \\
\text { sleepers, container flooring, truck } \\
\text { bodywork, and transmission posts. }\end{array}$ \\
\hline
\end{tabular}

Table 3: Light Hardwood

\begin{tabular}{|l|l|}
\hline \multicolumn{1}{|c|}{ Type of wood } & \multicolumn{1}{|c|}{ Wood description } \\
\hline $\begin{array}{l}\text { Nyatoh } \\
\text { Palaquium) }\end{array}$ & $\begin{array}{l}\text { Popularly used for furniture and high } \\
\text { class decorative interior finishing and } \\
\text { cabinet-making, strip and parquet } \\
\text { flooring, and others. }\end{array}$ \\
\hline $\begin{array}{l}\text { Sepetir } \\
\text { Sindora spp., } \\
\text { Copaifera } \\
\text { palustris.) }\end{array}$ & $\begin{array}{l}\text { Suitable for furniture, cabinet } \\
\text { making, and plywood manufacture. It } \\
\text { is highly valued as a decorative } \\
\text { timber and used in interior finishing, } \\
\text { joinery, paneling, high class cabinets } \\
\text { and furniture. }\end{array}$ \\
\hline $\begin{array}{l}\text { Meranti } \\
\text { Shorea spp.) }\end{array}$ & $\begin{array}{l}\text { A wide variety of uses including light } \\
\text { construction, furniture, joinery, } \\
\text { interior fittings, door and window } \\
\text { frames, paneling, partitions, utility } \\
\text { flooring, boat construction, fancy } \\
\text { doors, veneer and plywood. }\end{array}$ \\
\hline
\end{tabular}

